UDC 606:602:628

LBC 40.4

\title{
CLEANING OF FLOWS OF POULTRY FARMS WITH ECOLOGY ACCOUNTING AND RESOURCE SAVINGS
}

\author{
Aleksey V. Sklyar \\ Big Dutchman Ltd., Moscow, Russian Federation \\ Margarita V. Postnova \\ Volgograd State University, Volgograd, Russian Federation
}

\begin{abstract}
The possibilities of using non-biological methods for clarifying sewage from poultry farms are presented, which testify to the high efficiency of using electrochemical technologies. Unlike biological purification, the technology of electro-chemosorption clarification provides for a rigid treatment regime, when not only minerals, organic substances are oxidized, but also microorganisms and all persistent specific contaminants falling into the poultry drains occur. It has been revealed that electro-chemisorption plants can purify effluents to the maximum permissible concentrations over a wider range of contamination levels.
\end{abstract}

Key words: sewage, water, pollutants, treatment plants, electrochemical technologies.

УДК 606:602:628

ББК 40.4

\section{ОЧИСТКА СТОКОВ ПТИЦЕХОЗЯЙСТВ С УЧЕТОМ ЭКОЛОГИИ И РЕСУРСОСБЕРЕЖЕНИЯ}

\author{
Алексей Владимирович Скляр \\ ООО «Биг Дачмен», г. Москва, Российская Федерация
}

Маргарита Викторовна Постнова

Волгоградский государственный университет, г. Волгоград, Российская Федерация

\begin{abstract}
Аннотация. Представлены возможности применения небиологических способов осветления стоков птицеводческих хозяйств, свидетельствующие о высокой эффективности использования электрохимических технологий. В отличие от биологической очистки, технология электрохемосорбционного осветления предусматривает режим жесткой обработки, когда окисляются не только минералы, органические вещества, но и происходит деструкция микроорганизмов и всех стойких специфических загрязнителей, попадающих в пти$\infty$ цеводческие стоки. Выявлено, что электрохемосорбционные установки могут очищать стоки до предельно 尺े допустимых концентраций на более широком диапазоне уровней загрязнения.
\end{abstract}

ю Ключевые слова: стоки, вода, загрязнители, очистные сооружения, электрохимические технологии.

Стоки - неизбежные круглогодовые отходы всех птицеводческих хозяйств (ПХ), отличающиеся значительными объемами и большим числом загрязнителей воды. Соврем. менная бройлерная фабрика на 15 тыс. т мяса 5 за 12 месяцев сливает до 59 тыс. м ${ }^{3}$ стоков (?) (при условиях: мойки помещений и оборудо- вания высоконапорными насосами, минимизации стоков убойной линии и т. п.) [1;6]. Производя всеми ПХ Российской Федерации 4,3 млн т мяса птицы, только бройлерные предприятия должны очищать более 17 млн т стоков в год. Многократные анализы состава этих стоков говорят об относительно посто- 
янном составе, о большом числе и значительном варьировании уровней по каждому из загрязнителей. Например, замеры калужской Центральной лаборатории анализа и технических измерений (ЦЛАТИ) по стокам птицефабрики «Белоусово» выявили, что концентрация и виды загрязнителей следующие (мг/л): хлориды $(821,0)$, сульфаты $(60,3)$, азот аммонийный $(37,0)$, азот нитратов $(0,26)$, азот нитритов $(0,061)$, фосфаты по Р $(7,13)$, нефтепродукты $(0,048)$, анионные ПАВ $(0,827)$. Тестируемые стоки имели беловатый цвет, гнилостный запах (5 б), pH $(6,9)$, прозрачность (0), взвешенные вещества $(180,0)$, сухой остаток $(986,0)$ и БПК стоков в ПХ по типовым проектам строились очистные сооружения (ОС), в технологию которых были заложены флотационно-флокуляционные способы биохимического окисления и отделения части загрязнителей на первой стадии осветления стоков с доочисткой их в завершающей фазе на иловых площадках, биологических прудах и т. п. Сооружения и оборудование таких ОС занимают значительные площади, требуют больших капитальных и эксплуатационных затрат. Открытые отстойники, эмшеры, иловые площадки и биологические пруды становятся источниками попадания в атмосферу, воду и почву в зоне ОС всего содержимого стоков, включая носителей инфекций (испарения, перенос аэрозолей воздушными потоками, протечки стоков на почву, попадание их с осадками в открытые водоемы, в грунтовые воды и т. п.) [2; 5; 7]. Зимой в открытых бассейнах ОС коэффициент полезного действия (КПД) очистки снижается, иловые площадки и биологические пруды замерзая делаются неработоспособными. Наиболее существенным недостатком таких ОС является сама технология, не обеспечивавшая нужное качество ранее и тем более под высокие уровни предельно допустимых концентраций (ПДК) современных стандартов [3]. Данный факт подтверждается тем, что даже современные ступенчатые компакт-флотаторы ФДП-40 (ГК «Аргель») рассчитаны на КПД очистки по ХПК и БПК всего до $60 \%$.

Анализ возможностей использования небиологических способов осветления стоков ПХ свидетельствует о высокой эффективности электрохимических технологий, включая, например, цепное свободно-радикальное элек- трохимическое окисление с удалением основных органических и минеральных загрязнителей технической воды в сочетании с доочисткой ее в финишной фазе на ионообменных сорберах [4]. В отличие от биологической очистки, технология электрохемосорбционного осветления предусматривает режим жесткой обработки, когда окисляются не только минералы, органические вещества, но и происходит деструкция: штаммов вирусов, микроорганизмов (снижая ветеринарно-санитарную опасность) и всех стойких специфических загрязнителей, попадающих в птицеводческие стоки - частиц корма, подстилки, помета, пера-пуха, остатков удобрений, пестицидов, лекарственных препаратов и пр. Сущность метода электрохимической деструкции заключается в обработке сточной воды в электрореакторе с нерастворимыми в условиях анодной поляризации электродами. Глубина минерализации органических загрязнений при деструкции определяется как электродными редокс-процессами (катодное восстановление и анодное окисление), так и объемными реакциями под воздействием продуктов электролиза. Обеззараживание сточных вод при деструкции происходит ионами гипохлорита (которые образуются на аноде) и полученными при электрохимических процессах перекисью водорода, озоном. Учитывая вышеприведенный реальный уровень загрязнения стоков ПХ, новая установка должна иметь усредненные технические характеристики, соответствующие следующим показателям (мг/дм $\left.{ }^{3}\right)$ : взвеси - 2500, ХПК - 5000, БПК - 3000. Испытания комплекса средств очистки с такими параметрами показали, что рассматриваемое сочетание технологий позволяет осветлять стоки до уровней $\left(\right.$ мг/дм $\left.{ }^{3}\right)$ : ХПК -30 , БПК 600 , азот аммон. - 8,0, нитраты - 9, 1 , нитриты - 0,02, анион. ПАВ - 0,5, нефтепродукты 0,05 , фосфаты - 0,2, сульфаты - 80,0, хлориды - 1000, медь - 0,01, железо - 0,1, pH - 8,5 (все это должно быть в пределах ПДК). Выявлено также, что электрохемосорбционные установки могут очищать стоки до предельно допустимых концентраций на более широком диапазоне уровней загрязнения, например, по сухому остатку от 28-30, по ХПК от 12000 г/л. 
Конструктивная компоновка и схема работы очистителя стоков с электрохимическим окислением и сорберами выглядит следующим образом. Установка представляет собой модульный комплекс высокой степени заводской готовности (контейнер и емкости). Все стоки подаются со всех зданий ПХ канализационным насосом в резервуар-усреднитель модульного комплекса, перед которым размещается решетка для сбора крупного мусора. Далее установлен жироуловитель и бункера для первичной механической очистки.

Стоки из резервуара-усреднителя подаются погружными насосами в электрофлотатор, который обеспечивает удаление тонких взвесей, плавающих жиров, не осевших в жироуловителе, и коллоидных частиц. Для вывода загрязнителей на поверхность обрабатываемого объема сточной воды в электрофлотатор подается сжатый воздух от компрессорной установки, дезинфицирующий агент и регулятор кислотности. В напорной емкости происходит очистка стоков от аммонийного азота, жиров, плавающих, коллоидных примесей и снижение химического потребления кислорода. Из электрофлотатора частично очищенные стоки поступают в буферную емкость, откуда направляются в электролизер (реактор электроокисления), в нем происходит процесс окисления основной массы органических загрязнителей, аммонийного азота и восстановление нитритов и нитратов до азота.

Используются нерастворимые электроды, не содержащие драгметаллов (не требуется специальной лицензии для работы с драгметаллами). Из него стоки направляются в адсорбер (первая ступень сорбционной очистки), где происходит извлечение неполярных примесей, каталитическое доокисление и глубокая очистка от взвесей. Тонкую очистку осуществляют на второй ступени из параллельно распределенных потоков на фильтре с загрузкой ионообменными смолами, а на третьей ступени - с высокоселективными сор- бентами. Прошедшие очистку сточные воды поступают в емкость очищенной воды, откуда насосом подаются на сброс. Новые модульные комплексы очистки производственных стоков производительностью $0,4 \ldots 50 \mathrm{~m}^{3} / \mathrm{4}$ (10-438000 м $3 /$ год, их цены ниже всех биоочисток) хорошо зарекомендовали себя в эксплуатации на промышленных предприятиях от Сибири до Калининграда (в том числе на мясо- и рыбопереработке, свино- и птицекомплексах, последняя поставка - птицехозяйство «La Farm» Калужской области).

\section{СПИСОК ЛИТЕРАТУРЫ}

1. Биологическая мелиорация почв в проблеме экологизации земледелия / Н. Г. Ковалев [и др.] // Региональная экология. - 2015. № 6 (41). - C. 22-31.

2. Ветеринарно-санитарные и экологические условия при переработке птичьего помета / В. П. Лысенко [и др.] // Птица и птицепродукты. - 2011 № 3. - C. 13-16.

3. Миронов, В. В. Вопросы защиты окружающей среды от загрязнения отходами животноводства и птицеводства / В. В. Миронов // Инновации в сельском хозяйстве. - 2016. - № 5 (20). - С. 56-59.

4. Новиков, О. Н. Цепные свободнорадикальные процессы электроинициированного окисления в очистке сточных вод / О. Н. Новиков // Материалы научно-практической конференции «Наука XX1 веку», г. Волгоград, 25 октября 2013. - Волгоград, 2013. - С. 121.

5. Процессы самоочищения водных экосистем, подвергающихся воздействию отходов птицеводства / О. П. Неверова [и др.] // Аграрный вестник Урала. - 2013. - № 6 (112). - С. 68-70.

6. Степанов, С. В. К вопросу очистки сточных вод птицефабрик / С. В. Степанов, Ю. Е. Сташок, Е. В. Стукановская // Традиции и инновации в строительстве и архитектуре. Строительные технологии : сб. ст. Самарск. гос. архитектурно-строит. ин-та. - Самара, 2016. - С. 201-205.

7. Тюрин, В. Г. Птичий помет - критерии санитарно-ветеринарной оценки / В. Г. Тюрин, В. П. Лысенко // Птицеводство. - 2012. - № 2. - С. 50-52. 
A.В. Скляр, М.В. Постнова. Очистка стоков птицехозяйств с учетом экологии и ресурсосбережения

\section{Information about the Authors}

Aleksey V. Sklyar, Big Dutchman Ltd., Moscow, Russian Federation.

Margarita V. Postnova, Doctor of Sciences (Biology), Senior Researcher, Head of Department of Bioengineering and Bioinformatics, Volgograd State University, Prosp. Universitetsky, 100, 400062 Volgograd, Russian Federation, postnova@volsu.ru, biobio@volsu.ru.

\section{Информация об авторах}

Алексей Владимирович Скляр, ООО «Биг Дачмен», г. Москва, Российская Федерация. Маргарита Викторовна Постнова, доктор биологических наук, старший научный сотрудник, заведующая кафедрой биоинженерии и биоинформатики, Волгоградский государственный университет, просп. Университетский, 100, 400062 г. Волгоград, Российская Федерация, postnova@volsu.ru,biobio@volsu.ru. 